\title{
Vulnerability analysis of smallholder farmers to climate variability and change: an agro- ecological system-based approach in the Fincha'a sub-basin of the upper Blue Nile Basin of Ethiopia
}

\author{
Israel Tessema ${ }^{1,2^{*}}$ (D) and Belay Simane ${ }^{1}$
}

\begin{abstract}
Background: Ethiopia is frequently cited as a country that is highly vulnerable to climate variability and change. The country's high vulnerability arises mostly from climate-sensitive agricultural sector that suffers a lot from risks associated with rainfall variability. The vulnerability factors (exposure, sensitivity, and adaptive capacity) of the agricultural livelihoods to climate variability and change differ across agro-ecological systems (AESs). Therefore, the aim of this study was to analyze AES-specific vulnerability of smallholder farmers to climate variability and change in the Fincha'a sub-basin. We surveyed 380 respondents from 4 AESs (highland, midland, wetland, and lowland) randomly selected. Furthermore, focus group discussion and key informant interviews were also performed to supplement and substantiate the quantitative data. Livelihood vulnerability index was employed to analyze the levels of smallholders' agriculture vulnerability to climate variability and change. Data on socioeconomic and biophysical attribute were collected and combined into the indices and vulnerability score was calculated for each agro-ecological system.

Results: Considerable variation was observed across the agro-ecological systems in profile, indicator, and the three livelihood vulnerability indices-Intergovernmental Panel on Climate Change dimensions (exposure, sensitivity, and adaptive capacity) of vulnerability. The lowland AES exhibited higher exposure, low adaptive capacity, and high vulnerability, while the midland AES demonstrated lower exposure, higher adaptive capacity, and lower vulnerability. The wetland and highland AESs scored intermediate results.

Conclusion: Our results suggest that resilience-building adaptation strategies are vital to reduce the vulnerability of smallholder farmers. The measures taken should consider site-specific agro-ecological system requirements to reduce the vulnerability of smallholder mixed crop-livestock agriculture system. Since the approach based on the long-term realization of the community, any strategy designed based on such assessments is applicable to local condition.
\end{abstract}

Keywords: Vulnerability index, Exposure, Sensitivity, Adaptation capacity, Fincha'a sub-basin

\footnotetext{
* Correspondence: israel.tessema@aastu.edu.et

${ }^{1}$ Center for Environment and Development, College of Development Studies, Addis Ababa University, Addis Ababa, Ethiopia

${ }^{2}$ Environmental Engineering, College of Biological and Chemical Engineering,

Addis Ababa Science and Technology University, Addis Ababa, Ethiopia
} 


\section{Background}

Ethiopia, with a population of 94.4 million (Central Statistical Authority (CSA) 2013) is the second populous country in Africa. The country's economy is principally dependent on rain-fed agriculture; that is largely a "low input and low output" subsistence production system. The overwhelming proportion (95\%) of the cropped area and national annual crop production is under smallholder rain-fed farming (Tesfaye et al. 2015).

Ethiopia is frequently cited as a country that is highly vulnerable to climate variability and change (World Bank 2010; Conway and Schipper 2011; Tesfaye et al. 2015). Historically, Ethiopia is prone to climate-related hazards. Rainfall in Ethiopia is highly erratic; moreover, most rain falls intensively (often as convective storms) with very high variability spatially and temporally. Since the early 1980s, the country has suffered seven major droughts, five of which led to famines in addition to dozens of local droughts (Diao and Pratt 2007).

The nation's high vulnerability arises from: First, the heavy dependency of the economy on rain-fed agriculture and the risks associated with rainfall variability. Long-term records indicated repeated rainfall failures resulted in severe chronic food/feed insecurity, including famines due to significant loss of crops and livestock; Second, due to the low level of transfer and adoption of improved agricultural technologies and practices required to meet the production needs of the changing environment; Third, the topographical condition that causes severe land degradation problem coupled with the low adaptive capacity to adverse impacts of climate variability and change (Deressa 2006; Byerlee et al. 2007; World Bank 2010; Simane et al. 2014; Tesfaye et al. 2015).

In Ethiopia, in the last 50 years, the average annual minimum temperature has shown an increasing trend of $0.2{ }^{\circ} \mathrm{C}$ per decade (Tesfaye et al. 2015). The nation's rainfall is characterized by seasonal and inter-annual variability (Conway 2000; Seleshi and Zanke 2004). The annual rainfall variability in most part of the country remains above 30\% (Kindie et al. 2016). The part of the nation that experiences higher rainfall variability also has relative higher probability of crop failures (World Bank 2006). Evidence suggests that recurrent droughts and the associated food insecurity and famine in Ethiopia are mainly caused by climate, particularly rainfall variability (Conway 2000; Seleshi and Zanke 2004; World Bank 2006; Conway and Schipper 2011; Demeke et al. 2011). In terms of seasonal production, the Belg (April to June) season suffers from greater rainfall variability than the Kiremt (July to September) season, and most Belg season growing areas (eastern, northeastern, and southern part of the country) are suffering from unreliable onset of the season and frequent crop failures (Kindie et al. 2016).
Under climate variability and change, evidence suggests that changes in rainfall pattern cause relocation of suitable area of production for different crops in Ethiopian agriculture. Evangelista et al. (2013) showed that by 2020, the major cereal crops of Ethiopia such as maize, teff, sorghum, and barley will loss over 14, 11, 7, and 31\% of their current suitable area of production, respectively. On the same token, climate variability and change also affects duration of crop growth by slowing or hastening growth and development processes. Kassie et al. (2014), using two crop simulation models under various climate change scenarios, predicted a reduction of maize growth duration by 14 33 days in the central Rift Valley of Ethiopia in 2050 compared to the present due to higher temperature and variable rainfall conditions. Other impacts of climate variability and change on crop include the increase in prevalence and dynamics of crop pests and diseases in Ethiopia (Kindie et al. 2016).

Vulnerability means the propensity or predisposition to affect adversely and it encompasses a variety of concepts and elements including sensitivity or susceptibility to harm and lack of capacity to cope and adapt (IPCC 2014). There are two main types of vulnerability analysis or approaches that exist, namely outcome vulnerability or end-point vulnerability and contextual vulnerability or starting-point vulnerability (Kelly and Adger 2000; O'Brien et al. 2007; Füssel 2007; Nelson et al. 2010). A common string of both is an attempt to quantify multidimensional issues using indicators as proxies.

According to Adger (2006), the challenge of vulnerability research is to develop robust and reliable measures. Even the IPCC definition of vulnerability does not specify any particular assessment methodology or scale of analysis. One functional methodology at household and community levels is the Livelihood Vulnerability Index (LVI) adapted to the IPCC framework (LVI-IPCC) (Hahn et al. 2009; Simane et al. 2014). Under the umbrella of the framework, Hahn et al. (2009) developed an indicator-based vulnerability assessment that has been used by many researchers in different contexts (Pandey and Jha 2012; Shah et al. 2013; Etwire et al. 2013; Simane et al. 2014; Aryal et al. 2014; Asrat and Simane 2017; Amare and Simane 2017; Chala et al. 2017).

The LVI-IPCC is an execution of the sustainable livelihoods approach to development analysis (Chambers and Conway 1992). According to the approach, the communities described in terms of their natural capital, social capital, financial capital, physical capital, and human capital. It also involves studying how vulnerable a community or the system is as compared to others and the component that pushes up the level of vulnerability within the community (Simane et al. 2014).

Different scholars tried to study the vulnerability of Ethiopian farmers to climate-related extreme events. A 
research conducted by using panel data sets using a sample of 15 villages (Dercon et al. 2005), a research in the Blue Nile Basin (Ethiopia) by Temesgen et al. (2008), and analysis of rainfall variability and crop production in Amhara Region by Woldeamlak (2009) are a few to mention. The results of most of these studies are very general and aggregated at national levels.

There are also site-specific vulnerability studies conducted in other parts of the country like a research conducted in Dabus watershed (Ethiopia) by Asrat and Simane (2017), Muger sub-basin (Ethiopia) by Amare and Simane (2017), and study conducted in Didesa Basin Southern Part of Abay Basin (Ethiopia) by Chala et al. (2017) are identified. However, in tropical highlands where the majority of Ethiopian population resides, climatic and biophysical conditions change so dramatically over short distances. Therefore, aggregated national statistics do not capture the complex state of vulnerability at the local level (Simane et al. 2014). Hence, it creates a challenge for policy-relevant implementation of the LVI-IPCC framework in all places of the nation.

The Blue Nile River basin is one of the most sensitive basins to changing climate and water resources variability in the region (Kim and Kaluarachchi 2009). Specifically, the sub-basin is expressed as one of the erosion hot spot and vulnerable areas of the Blue Nile river basin (MoWIE 2014). Therefore, this study is conducted to assess the vulnerability levels of all agro-ecological systems (AES) found in Fincha'a sub-basin by using AES as a unit of analysis. The sub-basin is selected for the research because no similar study is conducted in the area before. Thus, it is imperative to understand at the local level the nature of climate variability and change vulnerability of smallholder farmers' agriculture. The relevance of AES-based generalization to household-level analysis allows us to map vulnerability profiles across the sub-basin. It is also important for adaptation planning and allows decision makers to understand patterns of vulnerability across relatively broad geographical locations. Although the study is site-specific, the findings obtained from the study provide context-specific contribution to the agro-ecological system based understanding of the impact of climate variability and change and adaptation responses given as a nation.

\section{Methodology}

\section{Description of the study area}

\section{Bio-physical setting of Fincha'a sub-basin}

Fincha'a sub-basin is 1 of the 18 sub-basins of the Blue Nile River basin. The Ethiopian part of Blue Nile River basin is also called Abay River Basin and is located in the northwestern region of Ethiopia between $7^{\circ} 40^{\prime} \mathrm{N}$ and $12^{\circ} 51^{\prime} \mathrm{N}$ latitude, and $34^{\circ} 25^{\prime} \mathrm{E}$ and $39^{\circ} 49^{\prime} \mathrm{E}$ longitude. The Abay River Basin has 16 sub-basins, which covers a total surface area of about $199,812 \mathrm{~km}^{2}$. The study sub-basin is specifically located in the south-central part of the Abay River Basin, western-central Ethiopia (Fig. 1).

Specifically, Fincha'a sub-basin located between $9^{\circ} 10^{\prime}$ $\mathrm{N}$ and $10^{\circ} 00^{\prime} \mathrm{N}$ latitude, and $37^{\circ} 00^{\prime} \mathrm{E}$ and $37^{\circ} 40^{\prime} \mathrm{E}$ longitude and has an area of about $3781 \mathrm{~km}^{2}$. The altitude of the sub-basin ranges approximately between 970 m.a.s.l, in the lowland of the Abay gorge located in the northern part of the sub-basin, and 3230 m.a.s.l, in Guddene mountain of Jima Geneti District. The highlands in the western and southern part of the sub-basin are higher in altitude, greater than 2300 m.a.s.l up to 3230 m.a.s.l.

The sub-basin has an annual rainfall ranging between 1367 and $1842 \mathrm{~mm}$. Lower annual rainfall was observed in the northern lowlands of the sub-basin and higher rainfall greater than $1500 \mathrm{~mm}$ was observed in the western and southern highlands of the sub-basin. About 73\% of the annual rainfall of the sub-basin falls between June and September. The annual maximum and minimum temperature in the sub-basin varies between 21.2-27.1 and 9.9-12.8 ${ }^{\circ} \mathrm{C}$, respectively. Adigrat Sandstone and Basalt mainly dominate the geology of the sub-basin. There are also Alluvium and Colluvium deposits. The dominant soils in the sub-basin are Alisols, Cambisols, and Nitosols, with the occurrence of Arenosols and Luvisols (Denekew and Bekele 2009).

The sub-basin is known for its land- and water-intensive development activities carried out by the government. There are three (Fincha'a, Amerti, and Neshe) hydroelectric dams within the sub-basin constructed in 1964, 1987, and 2014 respectively. Because of these dams, the community is forced to resettle in the other areas mostly to the slopped and more fragile ecosystem without any compensation other than those displaced by Neshe hydroelectric dam construction.

The land-intensive development activities coupled with increased population created different biophysical and socioeconomic environment problems. The Fincha'a Hydroelectric Dam alone inundated $120 \mathrm{~km}^{2}$ of a swamp, $100 \mathrm{~km}^{2}$ of grazing land, $18 \mathrm{~km}^{2}$ of cropland, and $1.2 \mathrm{~km}^{2}$ of forest. The $555 \mathrm{~km}^{2}$ grazing land in 1957 reduced to $332 \mathrm{~km}^{2}$ in 2001, and the area of cropland went up from 403 to $607 \mathrm{~km}^{2}$, indicating large-scale conversion of grazing land into cropland (Bezuayehu and Sterk 2008). The land use change decreased the number of livestock in the area due to the shortage of permanent grazing land. As an alternative, farmers are forced to use the swamp as pasture, which frequently results in the drowning of animals. The report also verified that the relocated communities resettled themselves in the hilly areas of the watershed, owning $23 \%$ less land and 24\% fewer livestock units (Bezuayehu 2006). 


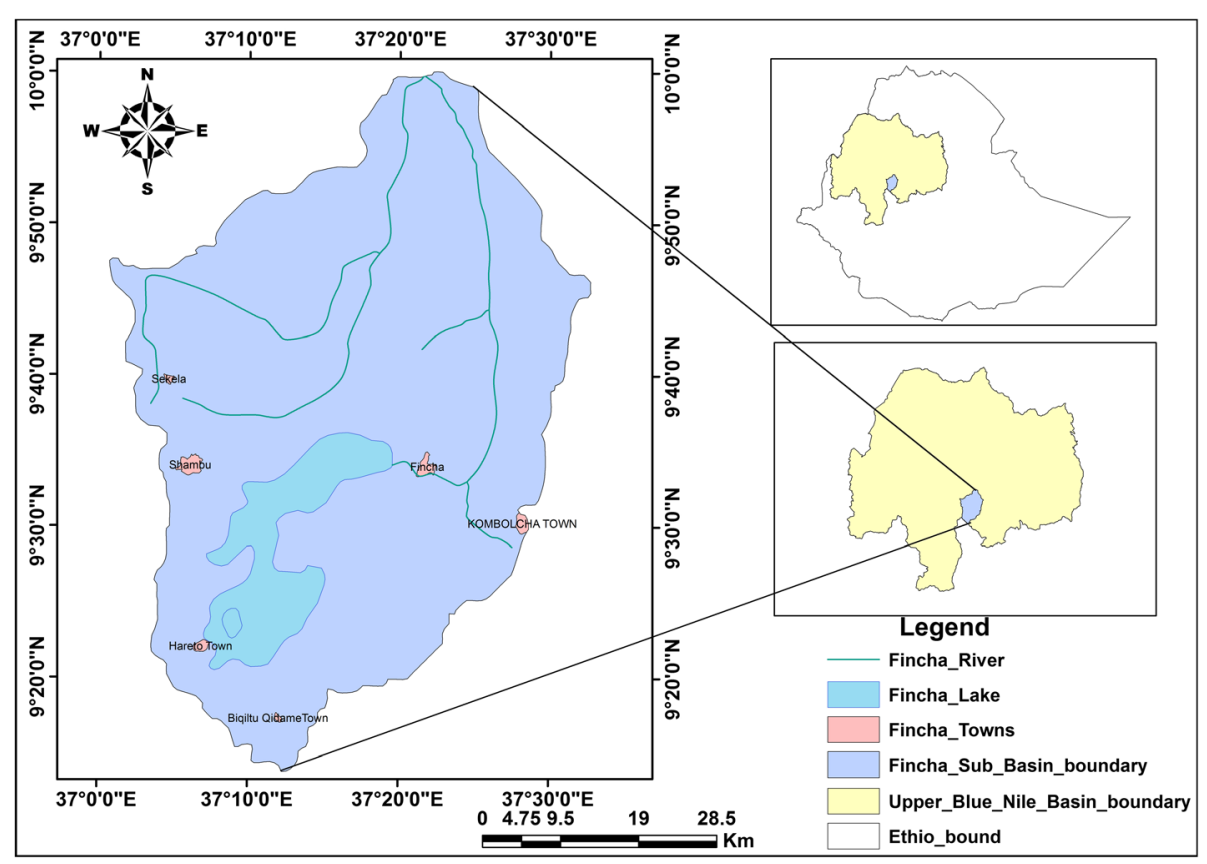

Fig. 1 Fincha'a sub-basin and its associated Blue Nile/Abay River basin

On the other hand, Dechassa (2003) argued that because of the Amerti dam project, the community in the area nowadays confronted with a decline in crop and livestock production and even recently with famine. The resettlement of farmers, who relocated from the dam site toward the higher and steeper parts of the sub-basin, has further aggravated the soil erosion problems which are a serious problem in the Ethiopian highland areas which threatened the agricultural sector (Hurni 1993) and causing increased sedimentation of reservoirs and lakes.

The other important problem in the sub-basin is land degradation and associated soil erosion. A study conducted by Bezuayehu and Sterk (2008) in Fincha'a watershed, part of the sub-basin, revealed that the proportion of the watershed exposed to possible maximum soil loss was cropland, amounting to $31 \%$ in $1957,36 \%$ in 1980 , and $46 \%$ in 2001. This shows that the area potentially subjected to accelerated erosion has been increasing from time to time. All the above-stated problems coupled with climate vulnerability and change expected to increase the vulnerability of the community in the sub-basin.

\section{Socioeconomic setting}

The Fincha'a sub-basin is administratively located in Oromia regional state, Horo Guduru Wollega Zone of Horo, Guduru, Hababo Guduru, Abay Chomen, Jima Geneti, Jima Rare, and Jardega Jarte Districts. According to CSA (2013) of Ethiopia population projection of 2014-2017, the total population of the sub-basin is assumed to be 577,467 and the average density of the population is about 153 people per $\mathrm{km}^{2}$. Densities are highest on the plateau and ridges of the sub-basin.

Agriculture is the main economic stay of the people residing within the sub-basin. The diversified agro-ecological systems with distinct climatic, soil, and altitude differences give an opportunity for growing a varied range of crops like cereals, oilseeds, pulses, and vegetables. Agriculture in the sub-basin is predominantly crop-livestock mixed systems, practiced by subsistence farmers on small plots. The result of the analysis of the sub-basin revealed that there are four agro-ecological systems (Highland, Midland, Wetland, and Lowland) found within the sub-basin. This gives an opportunity for the cultivation of range of crops like wheat (Triticum aestivum and Triticum durem) and barley (Hordeum vulgare) in the highland, teff (Eragrostis tef) and maize (Zea mays) in the midland and wetland, and maize (Zea mays) and sorghum (Sorghum bicolor) in the lowland agro-ecological systems of the sub-basin. There are also other cereal, pulse, oilseed, and vegetable crops grown in the sub-basin to provide food and income for the expanding population.

\section{Agro-ecological division of the sub-basin}

Agro-ecologically and agro-climatically, the sub-basin was subdivided into the following agro-ecological systems. System here represents the potentially vulnerable system such as a population, an economic sector, or a geographic area (Füssel 2007). The first is the highland with sloping terrain agro-ecological system (AES). This 
AES is confined to the sub-basin ridge above 2300 m.a.s.l in the Dega Agro-ecological Zone. Typically, the AES experiences cool and humid type of climate. It is characterized by steep (15\% to $30 \%)$ to very steep (> $30 \%)$ slopes. In terms of area coverage, it accounts for $21.9 \%$ of the sub-basin. According to sources formerly, the area is known for its overall high production potential, fertile soil, and producing surplus food. However, the high rate of deforestation, soil erosion, and landslide are the major environmental problems that jeopardized the overall productivity of the AES. The main crops grown in this AES are barley, wheat, pulses, and potatoes. In terms of area coverage, wheat and barley account for $35.1 \%$ and $26 \%$ respectively.

The second is midland with rolling plateau AES. This AES is dominantly characterized by midlands or Weinadega areas with an extensive rolling plateau, ranging in altitude between 1500 and 2300 m.a.s.l. The topography is predominantly undulating land and plains. Coupled with opportunities for market access, this livelihood zone is relatively food self-sufficient. It covers about $44.7 \%$ of the total area of the sub-basin. Soil types are dominantly loam and silt, sand and clay, which are relatively fertile. Teff, Niger seed, maize, wheat, and beans are produced very well in this AES. In terms of area coverage, teff, wheat, and Niger seed account for $26.2 \%$, $25.7 \%$, and $18.5 \%$ respectively. Households grow teff, maize, and wheat for consumption and sale while Niger seed is grown as a cash crop. This AES utilizes more agricultural inputs such as improved seed and inorganic fertilizer than the adjacent AES.

The third is the wetland AES. This AES includes the wetlands and the associated artificial lakes constructed for the generation of hydroelectric power. Crops like teff, maize, and horticultural crops grow best in this AES by draining the water. In terms of area coverage, teff and maize account for $43.2 \%$ and $36 \%$ respectively. Households grow teff, maize, and horticultural crops for consumption and sale. An important problem associated with this AES is wetland degradation that includes siltation due to soil erosion, and overexploitation of wetlands to farming activities due to dwindling of farmland (shortage of land). The siltation of the reservoir inundated the adjacent land that also escalated the farming and grazing land shortage. The implications of wetland degradation resulted in flooding, declining water quality, declining wetland biodiversity, declining water table, and water recharges.

The fourth is the lowland AES. This is a warm semiarid AES confined to the lower parts of the sub-basin along the Blue Nile gorge with an altitude range less than 1500 m.a.s.l. in the Kola Agro-ecological Zone. Typically, the AES experiences a hot type of climate. This specific AES accounts for $18.4 \%$ of the sub-basin.
High rate of soil erosion, unreliable rainfall, and insufficient supply of agricultural inputs (fertilizers, improved seeds, pesticides) are the major agricultural problems of this AES. The production of sorghum, maize, teff, sesame, and mung bean (Masho) crops is best known in this AES. In terms of area coverage, sorghum is the first and accounts for $35.8 \%$. Households grow sorghum and maize for home consumption, while sesame and mung bean are grown as cash crop.

\section{Research design and sampling procedure}

The research employed a two-stage sample design technique to select the Kebeles ${ }^{1}$ and households from the most general level (areas having similar Agro-ecological system) to the most precise level (household). In the first stage, the sub-basin is divided into similar agro-ecological systems. Based on the analysis, four agro-ecological systems (highland, midland, wetland, and lowland) were identified in the sub-basin. In the second stage, the seven districts found in the sub-basin were grouped into possible agro-ecological systems. Then, three representative districts (Horo, Jima Genete, and Hababo Guduru) that represent the four climate zones were selected randomly. The significance was to enable the research to focus on similarity and differences in vulnerability and adaptation strategy, depending on local context and circumstances, to climate variability and change on specific climate zone. Then two Kebles were randomly selected from the Districts representing each agro-ecological system (AES).

Finally, 380 mixed crop-livestock farming households were randomly selected living in 8 Kebeles (2 from each agro-ecological system), 95 households from each AES, participated in the cross-sectional survey. The survey was conducted from May to June 2017. The sampling frame (list of households residing in the Kebele) used for selection of households was obtained from Kebele administration.

The survey questions were designed in such a way to address the eight profiles used in calculating the LVI. They included inquiries on socioeconomic and environmental attributes as well as questions related to farmers' perceptions of climate change and adaptation methods. The surveyed farmers also asked questions about their observations regarding patterns of temperature and rainfall over the past 20 years. Household surveys paired with a biophysical survey to assess indicators related to land suitability, conservation practices, and irrigation potential. Focus group discussion (FGD) and key informant interview (KII) were also held at the community level in consultation with agricultural experts and development agents working at Keble level. The data obtained from the FGDs and KIIs were used to enhance the survey result. The data from the household survey also 
triangulated with focus group discussions and field observations data. Another source of information is rainfall and temperature data from 1995 to 2015 from the National Metrological station.

\section{Approaches for measuring vulnerability}

The integrated assessment approach was utilized to determine the vulnerability of Fincha'a sub-basin smallholder farmers to climate variability and change. The approach combines both socioeconomic and biophysical approaches to determine vulnerability. The "hazard-of-place model" (Cutter et al. 2000) and the vulnerability mapping approach (O'Brien et al. 2004) is a good example of this approach, in which both biophysical and socioeconomic factors are systematically combined to determine vulnerability.

Füssel (2007) and Füssel and Klein (2006) argued that the IPCC (2001) definition, which conceptualizes vulnerability to climate as a function of adaptive capacity, sensitivity, and exposure, accommodates the integrated approach to vulnerability analysis. According to Füssel and Klein (2006), the risk-hazard framework (biophysical approach) corresponds most closely to sensitivity in the IPCC terminology. Adaptive capacity (broader social development) is largely consistent with the socioeconomic approach (Füssel 2007). In the IPCC framework, exposure has an external dimension, whereas both sensitivity and adaptive capacity have an internal dimension, which implicitly assumed in the integrated vulnerability assessment framework (Füssel 2007) (Table 1).

As a methodology, this study adopted the livelihood vulnerability index (LVI) developed and demonstrated by Hahn et al. (2009) in Mozambique. Similarly, different authors used the same framework with some modification to major components to resemble the local context in Ethiopia (Asrat and Simane 2017; Amare and Simane 2017; Chala et al. 2017; Simane et al. 2014). The same methodology was employed in this study to assess the vulnerability of smallholder farmers to climate change and variability in Fincha'a sub-basin. The approach defined eight biophysical and socioeconomic profiles related to vulnerability based on review of literatures that match the conditions and constraints facing smallholder agricultural households in the sub-basin. The profiles include climate, ecosystem, agriculture, wealth, technology, infrastructure, community, and social network. Accordingly, the vulnerability index was derived for four agro-ecological systems found in the sub-basin. Each profile is composed of several indicators or sub-components. The eight vulnerability profiles were then mapped onto the three IPCC contributing factors to vulnerability. Each of the profiles, with the possible exception of climate profile, can also be associated with one of the five types of capital used in the sustainable livelihoods approach (Chambers and Conway 1992).

According to IPCC (2007), to determine the vulnerability of a household or community, vulnerability is calculated as a function of exposure, sensitivity, and adaptive capacity. The exposure includes the climate variability or change profile including the extreme events. The sensitivity includes the ecosystem and agricultural profiles. The adaptive capacity includes the wealth, technology, infrastructure, community, and social network profiles (Table 2). The indicators used to construct the profile for calculating the LVI selected based on primary data were generated through a household survey, focus groups discussion, key informant interview, expert opinion, and field observation made in the sub-basin.

\section{Calculating the LVI}

The study employed the indicator method for measuring vulnerability. In indicator method, vulnerability is quantified based on selecting indicators from the potential set of indicators and then combining them analytically to identify the levels of vulnerability (Hahn et al. 2009). In this study, all indicators of vulnerability are assumed to have equal importance and thus giving them equal weights (Cutter et al. 2000). The LVI calculation utilized the approach by Hahn et al. (2009). Different scholars (Simane et al. 2014; Panthi et al. 2015; Aryal et al. 2014; Mohan and Sinha 2010) also used a similar approach in various contexts.

As stipulated by Sullivan et al. (2002), the LVI uses a balanced weighted average approach, where each indicator contributes equally to the overall index even though each major profile is comprised of a different number of indicators or sub-components. The standardization for each index is required because each of the indicators or sub-components is measured on a different scale. The formula used for this conversion is adopted from the Human Development Index to calculate the life expectancy index, which is the ratio of the difference of the actual life expectancy and a pre-selected minimum, and the range of predetermined maximum and minimum life expectancy (UNDP 2007).

First, each indicator is standardized to a common scale:

$$
I_{V}=\frac{I_{a}-I_{\min }}{I_{\max }-I_{\min }}
$$

where $I v$ is the standardized value for the indicator, Ia is the value for the indicator $I$ for a particular AESa, $I_{\min }$ is the minimum value for the indicator across all the AESs, and $I_{\max }$ is the maximum value for the indicator across all the AES. For indicators, which are assumed to have an inverse relationship with vulnerability, the 
Table 1 Vulnerability factors, livelihood capitals, profiles, and indicators used for LVI analysis using the IPCC framework

\begin{tabular}{|c|c|c|c|c|c|}
\hline $\begin{array}{l}\text { Vulnerability } \\
\text { factors }\end{array}$ & $\begin{array}{l}\text { Livelihood } \\
\text { capitals }\end{array}$ & Profiles & Indicators & Units & Hypothesized functional relationship \\
\hline \multirow[t]{5}{*}{ Exposure } & & 1. Climate & $\begin{array}{l}\text { - Change in maximum } \\
\text { temperature }\end{array}$ & Changes over time, ${ }^{\circ} \mathrm{C}$ & \multirow[t]{5}{*}{$\begin{array}{l}\text { Larger change or frequency = higher } \\
\text { exposure }\end{array}$} \\
\hline & & & $\begin{array}{l}\text { - Change in minimum } \\
\text { temperature }\end{array}$ & Changes over time, ${ }^{\circ} \mathrm{C}$ & \\
\hline & & & - Change in precipitation & Changes over time, mm & \\
\hline & & & $\begin{array}{l}\text {-Climate-related hazards: } \\
\text { drought }\end{array}$ & $\begin{array}{l}\text { No of events over the last } \\
20 \text { years }\end{array}$ & \\
\hline & & & $\begin{array}{l}\text { - Climate-related hazards: } \\
\text { flood }\end{array}$ & $\begin{array}{l}\text { No of events over the last } \\
20 \text { years }\end{array}$ & \\
\hline \multirow[t]{8}{*}{ Sensitivity } & \multirow[t]{8}{*}{$\begin{array}{l}\text { Natural } \\
\text { capital }\end{array}$} & \multirow[t]{5}{*}{ 2. Ecosystem } & $\begin{array}{l}\text { - Land suitability for } \\
\text { agriculture }\end{array}$ & $\begin{array}{l}\text { Avg. scale values of soil } \\
\text { depth, terrain, drainage, and } \\
\text { fertility of }(1-5)\end{array}$ & \multirow[t]{5}{*}{$\begin{array}{l}\text { More forest cover, suitable land, } \\
\text { and access to irrigation = lower } \\
\text { sensitivity }\end{array}$} \\
\hline & & & $\begin{array}{l}\text { - Sustainability of land use } \\
\text { system }\end{array}$ & $\begin{array}{l}\text { The assumed intensity of } \\
\text { management (high, medium, } \\
\text { and low) }\end{array}$ & \\
\hline & & & $\begin{array}{l}\text { - Land cover change } \\
\text { (primarily deforestation/reforestation) }\end{array}$ & $\%$ change over the baseline & \\
\hline & & & $\begin{array}{l}\text { - Use of soil water conservation } \\
\text { techniques) }\end{array}$ & $\begin{array}{l}\% \text { of the land with SWC } \\
\text { structures }\end{array}$ & \\
\hline & & & - Irrigation potential & $\begin{array}{l}\text { Ha of land suitable for } \\
\text { irrigation }\end{array}$ & \\
\hline & & \multirow[t]{3}{*}{$\begin{array}{l}3 . \\
\text { Agriculture }\end{array}$} & - Annual total production (inverse) & $\begin{array}{l}\text { Tons of total product } \\
\text { harvested }\end{array}$ & \multirow[t]{3}{*}{$\begin{array}{l}\text { Greater productivity and } \\
\text { diversity = lower sensitivity }\end{array}$} \\
\hline & & & - Changes in productivity & Yield in tons/ha & \\
\hline & & & - The diversity of crop species & $\begin{array}{l}\text { Number of crops in the } \\
\text { system }\end{array}$ & \\
\hline \multirow{19}{*}{$\begin{array}{l}\text { Adaptive } \\
\text { capacity }\end{array}$} & \multirow{5}{*}{$\begin{array}{l}\text { Financial } \\
\text { capital }\end{array}$} & \multirow[t]{5}{*}{ 4. Wealth } & • Farm size & $\mathrm{Ha} / \mathrm{HH}$ & \multirow{5}{*}{$\begin{array}{l}\text { Greater wealth = greater adaptive } \\
\text { capacity }\end{array}$} \\
\hline & & & - Number of livestock & TLU/HH & \\
\hline & & & - Savings at the household level & $\begin{array}{l}\text { Amount of Birr (local } \\
\text { currency)/HH }\end{array}$ & \\
\hline & & & - Existing loans & Amount of Birr/HH & \\
\hline & & & - Non-agricultural income & $\begin{array}{l}\text { Amount of Cash obtained } \\
\text { per year }\end{array}$ & \\
\hline & \multirow{11}{*}{$\begin{array}{l}\text { Physical } \\
\text { capital }\end{array}$} & \multirow{4}{*}{$\begin{array}{l}5 . \\
\text { Technology }\end{array}$} & - Insecticide and pesticide supply & $\%$ of $\mathrm{HHs}$ using insecticide & \multirow{4}{*}{$\begin{array}{l}\text { Better access to technology = greater } \\
\text { adaptive capacity }\end{array}$} \\
\hline & & & - Fertilizer supply & $\%$ of HHs applying fertilizer & \\
\hline & & & - Improved seed supply & $\begin{array}{l}\% \text { of HHs using improved } \\
\text { seed }\end{array}$ & \\
\hline & & & • Irrigation potential & $\begin{array}{l}\% \text { of } \mathrm{HH} \text { s practicing } \\
\text { irrigation }\end{array}$ & \\
\hline & & \multirow{7}{*}{$\begin{array}{l}6 . \\
\text { Infrastructure }\end{array}$} & - Access to all-weather roads & Walking distance in hours & \multirow{7}{*}{$\begin{array}{l}\text { Better access to } \\
\text { infrastructure = greater adaptive } \\
\text { capacity }\end{array}$} \\
\hline & & & - Access to schools & Walking distance in hours & \\
\hline & & & - Access to veterinary services & Walking distance in hours & \\
\hline & & & - Access to markets & Walking distance in hours & \\
\hline & & & - Access to savings and credit & $\%$ of HHs using credit & \\
\hline & & & - Access to electricity & $\%$ of HHs accessing lights & \\
\hline & & & - Access to telephone & $\%$ of HHs using a telephone & \\
\hline & \multirow{3}{*}{$\begin{array}{l}\text { Human } \\
\text { capital }\end{array}$} & \multirow{3}{*}{$\begin{array}{l}7 . \\
\text { Community }\end{array}$} & - Sex of household head & Male/Female & \multirow{3}{*}{$\begin{array}{l}\text { More human capital, information } \\
\text { and services = greater adaptive } \\
\text { capacity }\end{array}$} \\
\hline & & & • Education level & $\%$ of $\mathrm{HH}$ heads & \\
\hline & & & - Availability of extension & No of DAs/village & \\
\hline
\end{tabular}


Table 1 Vulnerability factors, livelihood capitals, profiles, and indicators used for LVI analysis using the IPCC framework (Continued)

\begin{tabular}{|c|c|c|c|c|c|}
\hline $\begin{array}{l}\text { Vulnerability } \\
\text { factors }\end{array}$ & $\begin{array}{l}\text { Livelihood } \\
\text { capitals }\end{array}$ & Profiles & Indicators & Units & Hypothesized functional relationship \\
\hline & \multirow{9}{*}{$\begin{array}{l}\text { Social } \\
\text { capital }\end{array}$} & \multirow{9}{*}{ 8. Social } & - Skills/training & $\begin{array}{l}\text { No of training } \mathrm{HH} \text { head } \\
\text { attended }\end{array}$ & \multirow{9}{*}{$\begin{array}{l}\text { Fewer non-working days and } \\
\text { more tradition of working } \\
\text { together = greater adaptive capacity }\end{array}$} \\
\hline & & & - Health services & Walking distance in hours & \\
\hline & & & - Radio ownership & $\%$ of $\mathrm{HHs}$ who have a radio & \\
\hline & & & - Governance & $\begin{array}{l}1-5 \text { scale (election of } \\
\text { leadership) }\end{array}$ & \\
\hline & & & $\begin{array}{l}\cdot \text { Membership in social } \\
\text { organizations/CBO }\end{array}$ & $\begin{array}{l}\% \text { of } \mathrm{HHs} \text { who are members } \\
\text { of } \mathrm{CBO}\end{array}$ & \\
\hline & & & - Participation in projects & Participation index & \\
\hline & & & - Availability of bylaws & $\%$ of HHs who have bylaws & \\
\hline & & & $\begin{array}{l}\text { - Number of non-working } \\
\text { days/ month }\end{array}$ & $\begin{array}{l}\text { Average number of non- } \\
\text { working days in a month }\end{array}$ & \\
\hline & & & - The tradition of working together & $\begin{array}{l}\% \text { of } \mathrm{HH} \text { who have a } \\
\text { tradition of working together }\end{array}$ & \\
\hline
\end{tabular}

inverse scoring technique is applied in the standardization of values for each indicator based on ICRISAT (2006).

Inversed index values $(I v)=$ (maximum value - observed values for indicator $(I a)$ / (maximum value - minimum value).

Next, a profile average value is calculated as follows:

$$
P_{a}=\frac{\Sigma I_{v}}{N}
$$

where $\mathrm{Pa}$ is the value for one of the eight major profile in AESa, and $N$ is the number of variables in the profile. Values for each of the eight profiles then combined to obtain the AES level LVI:

$$
L V I_{a}=\frac{\sum_{p=1}^{E} N_{p} P_{a}}{\sum_{p=1}^{E} N_{p}}
$$

Where LVIa is the Livelihood Vulnerability Index for $\mathrm{AESa}$, and $\mathrm{Np}$ is the number of indicators in each profile.

The eight profiles combined according to the IPCC categorization scheme as follows:

$$
\mathrm{CF}_{a}=\frac{\sum_{p=1}^{f} N_{p} P_{a}}{\sum_{p=1}^{f} N_{p}}
$$

where $\mathrm{CF}_{\mathrm{a}}$ is an IPCC contributing factor (exposure $(E)$, sensitivity $(S)$, or adaptive capacity $(A)), f$ is the number of profiles associated with the contributing factor, and $P_{\mathrm{a}}$ is the indexed value to the profiles associated with the CF.

Finally, the LVI-IPCC for AESa is calculated as follows:

$$
L V I-I P C C_{a}=\left(E_{a}-A_{a}\right) * S_{a}
$$

The LVI-IPCC is scaled from - 1 (least vulnerable) to 1 (most vulnerable) and is best understood as an estimate of the relative vulnerability of compared populations.

\section{Results and discussion}

The vulnerability analysis results of all the agro-ecological systems (AESs) are presented in two different steps. First, the results obtained from the assessment of individual profiles and indicator's contributions to each of the profiles for each Agro-ecological systems are presented together with the overall LVI (Table 3, Fig. 2). Second, the LVI-IPCC vulnerability estimates done for the agro-ecological systems based on vulnerability components (exposure, sensitivity, and adaptive capacity) of climate vulnerability index are presented (Table 6, Fig. 3). The LVI provides information of which components determine vulnerability and the LVI-IPCC indicates which of the three factors (exposure, adaptive capacity, and sensitivity) influences the most when determining the vulnerability of the AESs. Finally, interaction among vulnerability components (exposure, sensitivity, and adaptive capacity) in each agro-ecological system (AES) is discussed.

\section{Livelihood vulnerability index results}

Table 3 presented indexed indicators, profiles, and overall Livelihood Vulnerability Index (LVI) for highland, midland, wetland, and lowland AESs. The livelihood vulnerability indices of the eight major profiles were also summarized in spider diagram (Fig. 2). In the diagram, the scale goes increasing from the 0.0 or center (less vulnerable) to 0.9 (more vulnerable) for the exposure and 
Table 2 Indexed indicators, profiles, and overall LVI for highland, midland, wetland, and lowland AESs

\begin{tabular}{|c|c|c|c|c|c|c|}
\hline \multirow[t]{2}{*}{$\begin{array}{l}\text { Profile/ } \\
\text { Component }\end{array}$} & \multirow[t]{2}{*}{ Indicators } & \multirow[t]{2}{*}{ Units } & \multicolumn{4}{|c|}{$\begin{array}{l}\text { Indexed value for } \\
\text { each indicator }\end{array}$} \\
\hline & & & $\mathrm{HL}$ & ML & WL & LL \\
\hline \multirow[t]{6}{*}{ 1. Climate } & $\begin{array}{l}\text { The standard deviation of the average daily maximum } \\
\text { temperature by month between } 1995 \text { and } 2015\end{array}$ & Changes over time, ${ }^{\circ} \mathrm{C}$ & 0.191 & 0.182 & 0.182 & 0.405 \\
\hline & $\begin{array}{l}\text { The standard deviation of the average daily minimum } \\
\text { temperature by month between } 1995 \text { and } 2015\end{array}$ & Changes over time, ${ }^{\circ} \mathrm{C}$ & 0.148 & 0.109 & 0.109 & 0.391 \\
\hline & $\begin{array}{l}\text { The standard deviation of the average monthly precipitation } \\
\text { between } 1995 \text { and } 2015\end{array}$ & Changes over time, $\mathrm{mm}$ & 0.293 & 0.269 & 0.269 & 0.484 \\
\hline & Average number of drought events in the past 20 years & Number of events & 0.630 & 0.149 & 0.183 & 1.000 \\
\hline & Average number of flood events in the past 20 years & Number of events & 0.359 & 0.000 & 1.000 & 0.755 \\
\hline & Profile indexed value & & 0.324 & 0.142 & 0.348 & 0.607 \\
\hline \multirow[t]{5}{*}{ 2. Ecosystem } & Land suitability for agriculture & Index & 0.500 & 0.000 & 0.500 & 0.750 \\
\hline & Sustainability of land use system & Index & 1.000 & 0.000 & 0.500 & 0.750 \\
\hline & Land with improved soil water conservation techniques & Percent & 0.263 & 0.221 & 0.484 & 0.210 \\
\hline & Irrigation potential & Hectare & 0.680 & 0.830 & 0.580 & 1.000 \\
\hline & Profile indexed value & & 0.611 & 0.263 & 0.516 & 0.678 \\
\hline \multirow[t]{4}{*}{ 3. Agriculture } & Average annual total production & Tons per $\mathrm{HH}$ & 0.652 & 0.629 & 0.742 & 0.682 \\
\hline & Average changes in productivity per hectare & Tons per $\mathrm{Ha}$ & 0.756 & 0.754 & 0.667 & 0.785 \\
\hline & The diversity of crop species (Inverse) & $1 /(\#$ of Crops +1$)$ & 0.533 & 0.571 & 0.571 & 0.615 \\
\hline & Profile indexed value & & 0.647 & 0.652 & 0.660 & 0.694 \\
\hline \multirow[t]{5}{*}{ 4. Wealth } & Average farm size of $\mathrm{HH}$ & Hectare per $\mathrm{HH}$ & 0.485 & 0.480 & 0.339 & 0.568 \\
\hline & Average number of livestock per $\mathrm{HH}$ & $\mathrm{TLU} / \mathrm{HH}$ & 0.479 & 0.432 & 0.347 & 0.277 \\
\hline & Average Existing loans per HH (Inverse) & $\mathrm{Birr} / \mathrm{HH}$ & 0.713 & 0.794 & 0.894 & 0.467 \\
\hline & Average non-agricultural income & $\mathrm{Birr} / \mathrm{HH}$ & 0.079 & 0.230 & 0.010 & 0.004 \\
\hline & Profile indexed value & & 0.439 & 0.484 & 0.397 & 0.329 \\
\hline \multirow[t]{5}{*}{ 5. Technology } & Households (HHs) who used Insecticide and pesticide & Percent & 0.040 & 0.105 & 0.088 & 0.174 \\
\hline & HHs who used fertilizer & Percent & 0.895 & 0.936 & 0.915 & 0.853 \\
\hline & HHs who used improved seed & Percent & 0.596 & 0.651 & 0.716 & 0.642 \\
\hline & HHs who have irrigation potential & Percent & 0.316 & 0.179 & 0.421 & 0.080 \\
\hline & Profile indexed value & & 0.462 & 0.468 & 0.535 & 0.437 \\
\hline \multirow[t]{8}{*}{ 6. Infrastructure } & Average time to access all-weather roads & Hours & 0.702 & 0.761 & 0.673 & 0.351 \\
\hline & Average time to access schools & Hours & 0.742 & 0.777 & 0.742 & 0.530 \\
\hline & Average time to access veterinary services & Hours & 0.731 & 0.757 & 0.731 & 0.574 \\
\hline & Average time to access markets & Hours & 0.613 & 0.747 & 0.693 & 0.427 \\
\hline & HHs who have access to savings and credit & Percent & 0.653 & 0.779 & 0.579 & 0.200 \\
\hline & HHs who have access to electricity & Percent & 0.042 & 0.137 & 0.000 & 0.000 \\
\hline & HHs who have access to telephone & Percent & 0.653 & 0.842 & 0.337 & 0.063 \\
\hline & Profile indexed value & & 0.591 & 0.686 & 0.537 & 0.306 \\
\hline \multirow[t]{7}{*}{ 7. Community } & Male-headed households & Percent & 0.867 & 0.960 & 0.960 & 0.930 \\
\hline & Household heads attended some level of school & Percent & 0.821 & 0.853 & 0.632 & 0.300 \\
\hline & Extension service received & Percent & 0.800 & 0.850 & 0.870 & 0.660 \\
\hline & Average number of trainings attended & Number & 1.000 & 1.000 & 1.000 & 0.000 \\
\hline & Average time to access health services & Hours & 0.514 & 0.549 & 0.480 & 0.411 \\
\hline & Radio ownership & Percent & 0.842 & 0.919 & 0.558 & 0.432 \\
\hline & Profile indexed value & & 0.807 & 0.855 & 0.750 & 0.456 \\
\hline 8. Social & Governance (\% of HHs participated in the election of leadership) & Percent & 0.870 & 0.843 & 0.842 & 0.789 \\
\hline
\end{tabular}


Table 2 Indexed indicators, profiles, and overall LVI for highland, midland, wetland, and lowland AESs (Continued)

\begin{tabular}{|c|c|c|c|c|c|c|}
\hline \multirow[t]{2}{*}{$\begin{array}{l}\text { Profile/ } \\
\text { Component }\end{array}$} & \multirow[t]{2}{*}{ Indicators } & \multirow[t]{2}{*}{ Units } & \multicolumn{4}{|c|}{$\begin{array}{l}\text { Indexed value for } \\
\text { each indicator }\end{array}$} \\
\hline & & & $\mathrm{HL}$ & $\mathrm{ML}$ & WL & LL \\
\hline & Membership in CBOs & $\%$ of $\mathrm{HHs}$ who are members of $\mathrm{CBO}$ & 0.895 & 0.915 & 0.920 & 0.821 \\
\hline & Participation in projects & Participation index & 0.412 & 0.618 & 0.471 & 0.324 \\
\hline & Availability of bylaws & Percent & 0.590 & 0.680 & 0.620 & 0.580 \\
\hline & Average number of non-working days per month & Number of Days & 0.558 & 0.642 & 0.592 & 0.125 \\
\hline & $\mathrm{HHs}$ who have the tradition of working together & Percent & 0.920 & 0.899 & 0.798 & 0.910 \\
\hline & Profile indexed value & & 0.708 & 0.766 & 0.707 & 0.591 \\
\hline
\end{tabular}

$H L$ highland, $M L$ midland, $W L$ wetland, and $L L$ lowland exposure and sensitivity components and higher vulnerability factor for adaptive capacity component. The highland and wetland AESs scored intermediate results and the details of the major profiles and its associated indicators discussed below

sensitivity components profiles and the inverse is true for the adaptive capacity component profiles. The major profiles or components that yield the LVI scores are elements of either of the five capital forms (natural, financial, physical, human, and social) and are grouped into the contributing factors namely exposure, sensitivity, and adaptation capacity in order to compute the LVI-IPCC (Table 3). Exposure includes the score of the climate profile; sensitivity is composed of two major profiles while adaptive capacity made up of aggregated scores of five major profiles.

Figure 2 depicts that lowland AES scored higher indexed value in climate, ecosystem, and agricultural profiles. In contrast, the lowland AES scored lower values in wealth, technology, infrastructure, community, and social profiles, whereas the midland AES scored lower indexed values in climate, ecosystem, and agriculture profiles and higher values in wealth, infrastructure, community, and social profiles. These imply that the lowland AES has higher vulnerability factors for exposure and sensitivity components and lower vulnerability factor for adaptive capacity component. In contrast, the midland AES has lower vulnerability factors for exposure and sensitivity components and higher vulnerability factor for adaptive capacity component. The highland and wetland AESs scored intermediate results and the details of the major profiles and its associated indicators are discussed below.

\section{Exposure vulnerability factor: climate profile}

This profile shows what is at risk in view of exposure to climate variability or change. The climate profile includes the climate variability and change, and the natural hazards (weather extreme events) indicators and encompasses five indicators. The analysis of the profile revealed that the lowland AES is more vulnerable by exposure vulnerability factor (EVF) (0.607), whereas the midland AES was found to be the least vulnerable by EVF (0.142) (Table 2). The wetland and highland AESs scored 0.348 and 0.324 respectively, which is an intermediate result in terms of the profile average value.

The result of the analysis reveals that the lowland AES higher vulnerability arises from the four of the contributing factors. First, the average number of drought events in the past 20 years was the highest for lowland AES (3.58) as compared to 2.81, 1.88, and 1.81 for highland, wetland, and midland AESs respectively. The other weather extreme event that determines the vulnerability of lowland AES is the exposure to flooding. In the past 20 years, the lowland AES exposed to flooding on average 4.52 times as compared to 2.95 and 1.53 for highland and midland AESs respectively. The exposure to flooding event is the highest in wetland AES, which was 5.49 times. Another contributing factor for the higher vulnerability of the lowland AES in climate profile is the average monthly temperature and precipitation change observed in the area as compared to the other agro-ecological systems. In addition to data collected from the national metrological agency, the perception of the community about the change of the different climate parameters collected and $96.8 \%$ and $56 \%$ of the community responded that there is an increasing trend of temperature and decreasing trend of precipitation

Table 3 Continuous variables considered in the ANOVA analysis for the four AESs

\begin{tabular}{|c|c|c|}
\hline Variable & $F$ test & Significance level \\
\hline The total hectare of land the household owned & $34.258^{* * *}$ & 0.000 \\
\hline Average production gained at household level in quintals & $14.941^{* * *}$ & 0.000 \\
\hline Hectare of land under irrigation & $7.639^{* * *}$ & 0.000 \\
\hline Size of land with improved soil and water conservation measures in a hectare & $12.452^{* * *}$ & 0.000 \\
\hline
\end{tabular}




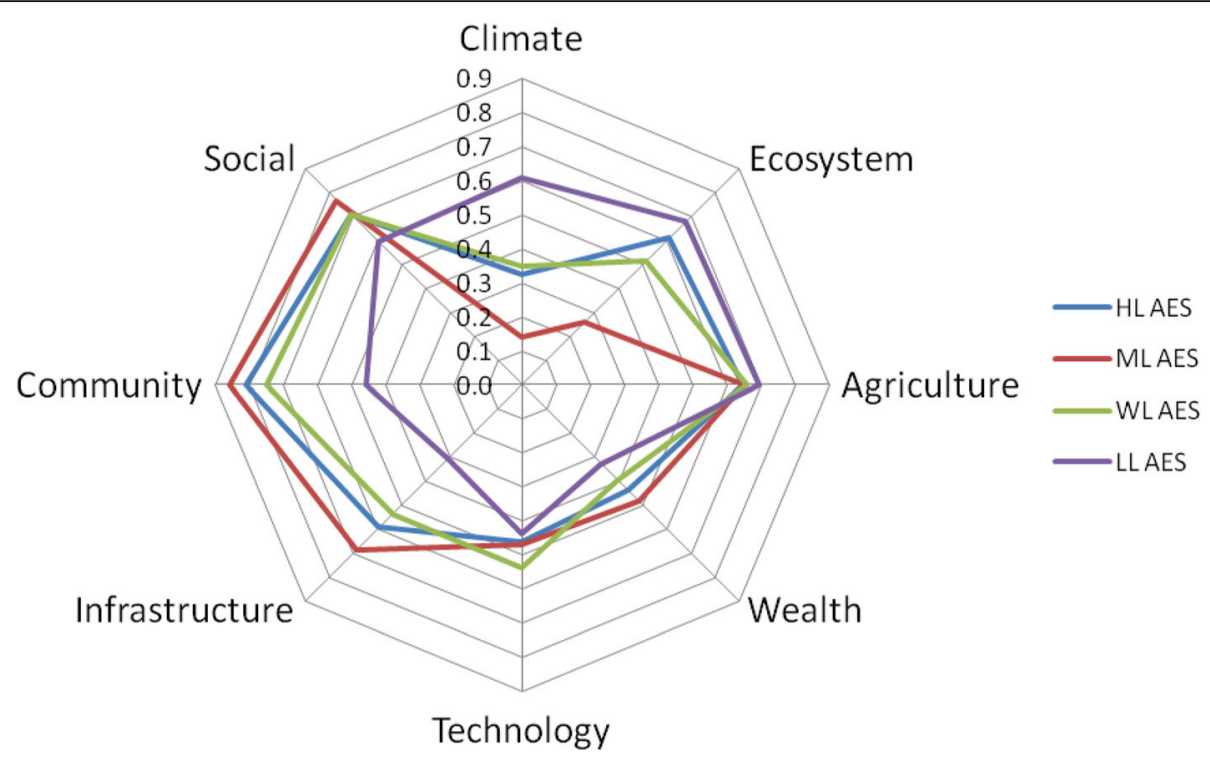

Fig. 2 Spider diagram of major profiles of Livelihood Vulnerability Index (LVI)

respectively in the lowland AES. Generally, by considering farmers' perception and substantiating it with objective metrological record of the past 20 years, the variability in the average maximum monthly temperature and precipitation has been relatively greater in the lowland agro-ecological system than the corresponding AESs.

\section{Sensitivity vulnerability factor: ecosystem and agriculture profiles}

Sensitivity of a system reflects the degree of response to a given change in climate. Thus, the biophysical effects of climate change are broadly grouped under the sensitivity component. These include the changes in the natural ecosystem as well as managed systems such as agriculture (Mohan and Sinha 2010). Variations in ecosystem and agricultural profiles together govern the sensitivity levels of agro-ecological systems.

Ecosystem profile Land suitability, sustainability of land use system, soil and water conservation practice, and irrigation practices have been chosen as the indicators of the ecosystem profile. Based on the calculated indices of the indicators, the lowland, highland, wetland, and midland AESs scored 0.678, 0.611, 0.516, and 0.263 average profile values respectively. The profile average value revealed that the lowland AES has higher vulnerability score, whereas the midland AES has lower vulnerability score. The land suitability for agriculture analysis of the study found that the relative suitability potential of the study sub-basin from highest to the lowest in descending order becomes midland, wetland, highland,

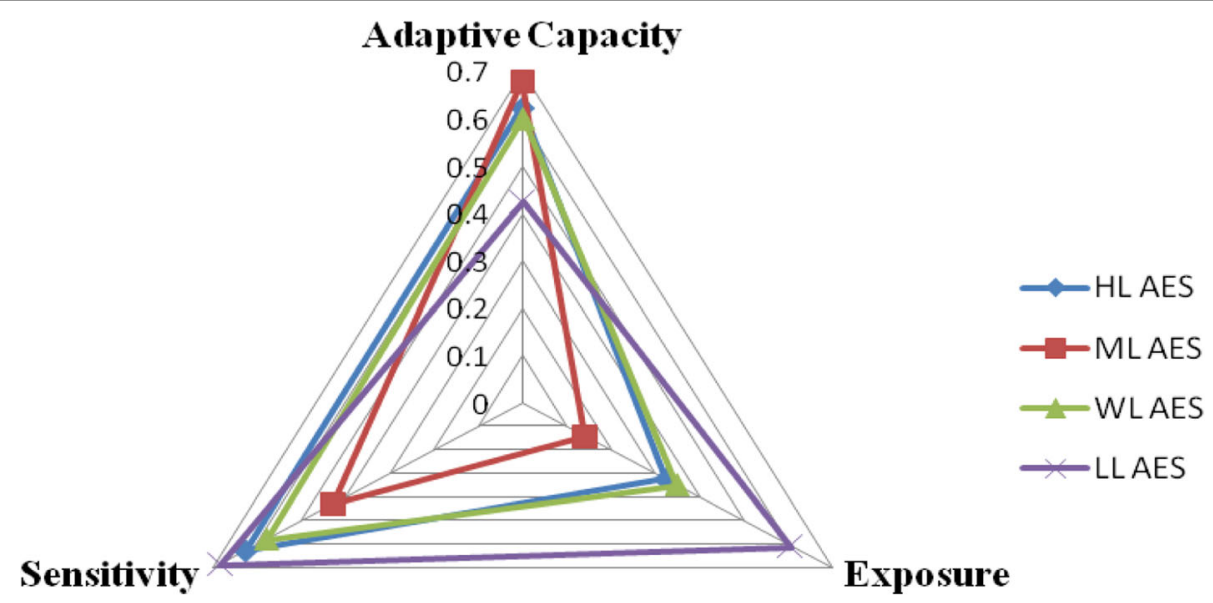

Fig. 3 Vulnerability triangle diagram of the dimensions of Climate Vulnerability Index (CVI) 
and lowland AESs respectively, which is characterized by their relative slopes, productivity of the soils, and the prevailing climatic condition. Suitability is lower in lowland AES, which is affected by the low fertility of soils, landslide, high rate of soil erosion, and rainfall variability. In terms of irrigation potential, the wetland and highland AESs have the highest potential, whereas the lowland AES has the least potential.

The highland AES is suffering a lot from severe land degradation problem in the sub-basin. Specifically, in terms of erosion problem, the sub-basin is expressed as one of the erosion hot spot areas of the Blue Nile river basin (MoWIE 2014). In the highland AES, the reality is that the steepness of the slope is higher and natural ecosystems have been and being converted to agricultural fields. Consequently, the infiltration and percolation rate of the water to the soil and ground water becomes lower. In contrast, the surface runoff becomes higher; this is coupled with increased velocity by the steepness of the slope, and aggravated the problem of soil erosion in this specific AES. The erosion problem is causing onsite productivity reduction by land and nutrient loss and offsite reservoir sedimentation of the hydroelectric dams, and flooding and sedimentation of the agricultural fields of the same AES and wetland AES in the downstream areas.

According to sources from zonal and district agricultural offices, the problem of land degradation in general and soil erosion in particular are severe. In contrary, measures taken to avert the situation of land degradation were minimal as compared to the required intervention. The result of land with improved soil and water conservation indicator revealed that the relative intervention is higher in highland and lower in the wetland ACL. One-way ANOVA reveals that the mean difference among the agro-ecosystem is statistically significant at $(P<0.001)$ level for land with improved soil and water conservation measures (Table 4).

Agricultural profile There are three indicators in agricultural profile. The profile indices for the lowland, wetland, midland, and highland AESs are 0.694, 0.660, 0.652 , and 0.647 respectively. The vulnerability difference among the agro-ecological systems in this profile is minimal. However, there are differences among the AES in terms of the indicators values. On average, annual total production per household indicator, the highest in midland AESs (2.93 tons/ $\mathrm{HH}$ ) and the least is in wetland AES (2.04 tons/HH). The lower amount of production in wetland AES is accounted from the lowest per capita land holding size in this AES. The result of the indicator interpreted as the higher the productivity the lesser the vulnerability.

In terms of average positive changes in productivity per unit area (hectare), the study revealed that the highest is in the wetland $(0.32$ tons $/ \mathrm{Ha})$, whereas the least is in lowland AES $(0.21$ tons $/ \mathrm{HH})$. The highest productivity change of the wetland AES is accounted from the highest agricultural technology usage of the farmers in the AES. In terms of crop diversity indicator, the highest was found in highland and the least in lowland AES. The result interpreted as the higher the crop diversity the lower the vulnerability. Diversified source of livelihood minimizes the vulnerability of the community to climate variability and

Table 4 Explanatory variables considered for ANOVA for the four agro-ecological systems

\begin{tabular}{|c|c|c|}
\hline Variable & $F$ test & Significance level \\
\hline Educational status of the household head in year & $39.711^{* * *}$ & 0.000 \\
\hline Age of the household heads in year & $55.358^{* * *}$ & 0.000 \\
\hline Average number of non-working days per month & $175.317^{* * *}$ & 0.000 \\
\hline Time spent to access all-weather roads & $110.234^{* * *}$ & 0.000 \\
\hline Time spent to access the nearest schools & $39.774^{* * *}$ & 0.000 \\
\hline Time spent to access Health services & $7.634^{* * *}$ & 0.000 \\
\hline Time spent to access veterinary services & $10.562^{* * *}$ & 0.000 \\
\hline Distance to water sources & $2.263^{*}$ & 0.081 \\
\hline Access to piped water sources & $16.889^{* * *}$ & 0.000 \\
\hline Time spent to access the nearest input-output market & $64.977^{* * *}$ & 0.000 \\
\hline Distance to saving and credit institution & $36.097^{* * *}$ & 0.000 \\
\hline Access to saving and credit institution whenever required & $29.084^{* * *}$ & 0.000 \\
\hline Access to electricity & 0.9882 & 0.000 \\
\hline Access to telephone & $61.602^{* * *}$ & 0.000 \\
\hline Access to radio & $25.256^{* * *}$ & 0.000 \\
\hline
\end{tabular}

${ }^{*},{ }^{* *},{ }^{* * *}$ Significant at $10 \%, 5 \%$, and $1 \%$ respectively 
change (Turner II et al. 2003). One-way ANOVA for household land holding in hectare, average production gained in quintals, and land under irrigation among the agro-ecological systems is statistically significant $(P<0.001)$ (Table 4).

\section{Adaptive capacity vulnerability factor}

Adaptive capacity designates the capacity to cope with the changes and adapt to changing condition. It is dependent on several socioeconomic factors such as wealth, agricultural technology usage, infrastructure development, community, and social capital profiles (Asrat and Simane 2017; Amare and Simane 2017; Simane et al. 2014; Mohan and Sinha 2010). Each detail of the profile and indicator values of the respected agroecological system is presented in Table 3. The higher adaptive capacity implies the lower the vulnerability of the agro-ecosystem.

Wealth profile The wealth profile is composed of four indicators that include average farm size of $\mathrm{HH}$, average number of livestock per $\mathrm{HH}$, average existing loans per $\mathrm{HH}$ (Inverse), and average non-agricultural income. The analysis of the profile revealed that the lowland AES is more vulnerable by profile average value of (0.329), whereas the midland AES found to be the least vulnerable by profile average value of (0.484). The highland and wetland AES scored 0.439 and 0.397 respectively, which is an intermediate result in terms of the profile average value. The higher vulnerability of the lowland AES is presumably accounted from the lower livestock ownership, higher average existing loans per household, and minimal average non-agricultural income. According to per capita livestock holding, the highest is in the highland AES (5.57 $\mathrm{TLU}^{2}$ ) and the least is 3.23 TLU in the lowland AES. In line with this, the inverse average livestock unit (TLU) LVI score for indicator is 0.479 for the highland AES and 0.277 for the lowland AES. The result interpreted as the higher per capita livestock holding means the higher adaptive capacity (Table 3 ).

The other indicator in this profile is the average farmland size holding. Farmland size and vulnerability have inverse functional relationship; that is, as farmland size increases, vulnerability decreases and vice versa (O'Brien et al. 2004). This is true because it provides an opportunity for crop diversification and implementation of soil conservation measures. Otherwise, vulnerability and adaptive capacity attributed more to utilization and productivity than the absolute land holding (Asrat and Simane 2017). In terms of this indicator, the highest is in lowland (2.13 ha) and the least in wetland AES (1.27 ha) which is almost equal to the national average of 1.22 ha (CSA 2012). However, lowland AES is more vulnerable than the wetland AES. Therefore, this entails that vulnerability may not solely be determined by farmland holding size rather by agricultural technological usage, and overall management of the system. In terms of these indicators, the wetland AES is better than the lowland AES.

The income from non-agricultural (off-farm) activities is the highest in the midland AES and the least in the lowland AES. However, the analysis revealed that the overall non-agricultural income in the sub-basin is minimal. These imply that the farmers in the sub-basin are more dependent in the agricultural (crop and livestock) income. The larger dependence on agriculture greatly increases household vulnerability since any crop problems like climate variability and change can cause remarkable reductions of income. In terms of average existing loans indicator, the highest is in the lowland AES and the least is in the wetland AES. This indicator has an inverse relationship with adaptive capacity because a household with higher load increases the likelihood of its vulnerability.

Technology profile The other profile in this vulnerability factor is the technology usage. In this profile, there are four indicators. The technological usages of the farmers determine their level of vulnerability. We assumed as agricultural technology usage increases, productivity proportionally increased and level of vulnerability reduced. There are three indicators in this profile. The profile indices for the wetland, midland, highland, and lowland AESs are $0.535,0.468,0.462$, and 0.437 respectively. Based on indices value, it is clear that the wetland AES is better in terms of adaptive capacity. The higher adaptive capacity of the wetland AES attributes by relatively high number of agricultural inputs users.

The higher average changes in productivity per hectare of wetland AES in agriculture profile are attributed due to higher usage of agricultural technologies like improved seed and fertilizer application. The least technology usage, which entails lower adaptive capacity and highest vulnerability (0.437) of lowland AES, can be associated with low agricultural input usage (fertilizers, improved seeds, pesticides) and almost nil irrigation practice of the surveyed households in this AES. The percentage of farmers who have applied chemical fertilizers across all AESs in the Fincha'a sub-basin is high with an average of about $90 \%$ having used chemical fertilizer. However, the total amount of chemical fertilizer applied is low and below the recommended rate, even among farmers that report using some fertilizer.

Generally, according to sources from the zonal and district agricultural offices and verified during focus group discussion, farmers in the sub-basin have long tradition of using agricultural inputs (fertilizers, improved seeds, pesticides); however, insufficient supply of these inputs is the major problem in the area. Concerning livestock, lack of 
sufficient feed (fodder), low performance of the local breeds, inadequate veterinary service, and high prevalence of animal diseases are some of the constraining factors that adversely affect livestock productivity in the sub-basin.

Infrastructure profile Another important factor determines the level of vulnerability of smallholder's farmers residing in the study area. Indicators of infrastructure like access to primary school and access to telephone services in highland and midland AESs are relatively comparable to the national average. Other infrastructures like access to all weather road, marketing, access to veterinary services, and electricity are minimal. Generally, road infrastructure development and electricity access of the sub-basin has many problems.

Out of the total seven indicators included in the infrastructure profile, the analysis for time spent to access to all weather roads, to access schools, to access veterinary services, and to access the input and output market have an inverse functional relationship with vulnerability. That is, as time spent to access services decreases, adaptive capacity increases, and vulnerability decreases and vice versa. For example, based on survey result, the average time spent to access all weather roads in midland, highland, wetland, and lowland AESs are 0.9, 1.1, 1.2, and $2.3 \mathrm{~h}$ respectively. The inversed indexed value for the indicator becomes $0.761,0.702,0.673$, and 0.351 for midland, highland, wetland, and lowland AESs respec tively. Therefore, it is evident that as the time spent increases, adaptive capacity reduces and vice versa for indicator in specific agro-ecological system. The same procedure followed to determine the indices of access to schools, access to veterinary services, and access to the input and output market indicators of the profile.

In the access to electricity indicator, out of the total surveyed households, $86.3 \%$ in midland AES, $95.8 \%$ in highland AES, and $100 \%$ in wetland and lowland AESs have no access to electricity. It is a paradox that the sub-basin is the source of two hydroelectric powers for the nation but suffering a lot from accessing the electricity sources. The highest infrastructure profile value is observed in the midland AES (0.686) and the least profile value is observed in the lowland AES (0.306). The higher profile value means the lower vulnerability and the lower profile value means the higher vulnerability. The highland (0.591) and wetland (0.537) AESs scored intermediate results.

One-way ANOVA reveals that there exists a significant difference of time spent to access all-weather roads, time spent to access the nearest schools, time spent to access veterinary service, distance to the nearest input-output market, distance to saving and credit institution, and access to telephone among the four agro-ecological systems (Table 4). Generally, insufficient access to infrastructural services persuades vulnerability of smallholder farmers to climate-related risks and in effect, it induced inefficient input and output market, low agricultural production, and less adaptive capacity.

Community profile The profile has six indicators and the profile indices for the midland, highland, wetland, and lowland AESs are 0.855, 0.807, 0.750, and 0.456 respectively. In this profile, the midland AES has higher adaptive capacity and the lowland AES has lower adaptive capacity. The higher adaptive capacity means the lower vulnerability and vice versa. The relative level of school attended by the household head, the number of extension workers available, the climate-specific extension service received, the average time spent to access the health facility, and the percentage of households that owned radio are the indicators that determine the vulnerability of the lowland AES.

Education and training received believed to have the potential influence on farmers' decision and positively contribute to climate change adaptation. In terms of literacy level, about $85.3 \%, 82.1 \%, 63.2 \%$, and $30 \%$ of the respondents have attended some level of education in midland, highland, wetland, and lowland AES respectively. One-way ANOVA analysis reveals that there exists a significant difference of educational status of the household head, time spent to access health services, and ownership of radio among the four AES (Table 4).

Social profile The social network is another important profile that determines the vulnerability of the community. Social profile evaluates the social capital like norms, values, and attitudes that predispose people to cooperate; develops trust, reciprocity, and obligation; and establish common rules and sanctions mutually agreed upon it (Cramb and Culasero 2003; Pretty 2003). The social profile component has the highest adaptive capacity scores in midland (0.766) than the lowland (0.591), wetland (0.707), and highland (0.708) AESs. The higher vulnerability of the lowland AES attributed by low level of participation in leadership selection, low level of membership in community-based organization, least farming experience, and the highest level of non-working days per month.

Farming experience is one indicator used to determine the social profile value of the agro-ecological systems. We expected that farming experience provides the opportunity to moderate vulnerability to climate change impacts through adjustments in terms of choosing appropriate crop types and varieties, selection of optimal planting date, practicing relevant cultural, and management practices (Gutu et al. 2012). The survey result reveals that farmers of highland and wetland AESs have 
24 years of experience, whereas the midland and lowland AESs have 21 and 19 years of experience respectively. Hence, farmers of the lowland AES have low chance of making possible adjustments to anticipated impacts of climate variability and change as compared to the other agro-ecological systems.

Another indicator under the social profile, average non-working days per month, disclose that farmers of the lowland, highland, midland, and wetland AESs have on average 10.5, 5.3, 5.3, and 4.9 non-working days per month. One-way ANOVA reveals that the average number of non-working days per month is significantly different $(P<0.001)$ among the four agro-ecosystems (Table 4). The result interpreted as the higher the non-working days, the lower the adaptive capacity and the higher the vulnerability of the community in specific agro-ecological system.

\section{Livelihood capitals and relative vulnerability index of AESs}

Table 5 presents the vulnerability of the community residing in different agro-ecological system of the sub-basin from the livelihood perspective. The first livelihood capital is natural capital that includes the ecosystem and agriculture profiles. In each of the profiles, there are different indicators, which explain the resource availability and its sustainability use. This livelihood capital categorized with sensitivity vulnerability factor and we hypothesized that vulnerability increases with an increase in the sensitivity of the system, as household livelihoods are more at risk from substantial changes in climate. The result revealed that the lowland AES (0.686) is the highest vulnerable, whereas the midland AES (0.457) is the least vulnerable in terms of natural capital. The other AESs scored intermediate values.

Financial, physical, human, and social livelihood capitals fall under the vulnerability factor of adaptive capacity. In other way, adaptive capacity analysis was conducted using access to and control over the livelihood capitals/resources. The financial capital includes the wealth profile (farmland size, number of livestock, non-agricultural income, and household loans indicators). We hypothesized that as financial capital of a household increased,

Table 5 Livelihood capitals and relative vulnerability of agroecological systems

\begin{tabular}{llllll}
\hline \multirow{2}{*}{$\begin{array}{l}\text { Livelihood } \\
\text { capitals }\end{array}$} & $\begin{array}{l}\text { Vulnerability } \\
\text { factors }\end{array}$ & \multicolumn{5}{l}{ LVI results of AESS } \\
\cline { 3 - 6 } & & $\mathrm{HL}$ & $\mathrm{ML}$ & $\mathrm{WL}$ & $\mathrm{LL}$ \\
\hline 1. Natural capital & Sensitivity & 0.629 & 0.457 & 0.588 & 0.686 \\
2. Financial capital & Adaptive capacity & 0.439 & 0.484 & 0.397 & 0.329 \\
3. Physical capital & Adaptive capacity & 0.526 & 0.577 & 0.536 & 0.372 \\
4. Human capital & Adaptive capacity & 0.807 & 0.855 & 0.750 & 0.456 \\
5. Social capital & Adaptive capacity & 0.708 & 0.766 & 0.707 & 0.591 \\
\hline
\end{tabular}

vulnerability decreased. For example, a household who has more livestock could cope with any disaster related to climate variability and change at least for a short period by selling their livestock. In terms of financial capital, the lowland AES (0.329) is more vulnerable than the other AESs, whereas the midland AES (0.484) is the least vulnerable.

The other livelihood capital is physical capital that includes the technological and infrastructure profiles. From the livelihood perspective, we hypothesized that the increased availabilities of technologies (like improved seed, fertilizer, and irrigation) and accessibility to different services (like road, school, veterinary services, market, and credit services) reduce vulnerability. The lowland AES with an indexed value of 0.372 is the highest vulnerable and the midland AES (0.577) is the least vulnerable in terms of physical capital.

We identified six indicators of human capital, sex of household head, education, extension services, training attended about available options, time spent to access health services, and ownership of radio. From the viewpoint of livelihood, we hypothesized that the male, more educated, household who have access to extension services, informed and more aware, healthy community, and who owned radio could adapt more to climate variability and change with available livelihood capitals. In terms of this capitals, the midland, highland, wetland, and lowland AESs scored 0.855, 0.807, 0.75 and 0.456 indices respectively. The result revealed that the lowland AES is the highest and the midland AES is the least vulnerable.

The last livelihood capital is the social capital. Another important capital determines the vulnerability of the community within the agro-ecological systems. The social capital of the livelihood capital component has the highest indexed value scores in midland (0.766) than the lowland (0.591), wetland (0.707), and highland (0.708) AESs. The higher indexed social capital value implies the lower vulnerability of the agro-ecological system and vice versa.

\section{LVI-IPCC vulnerability estimate}

The profile and composite LVI for each AES is calculated using the methodology in Eqs. (1)-(5) and the results produce vulnerability factors measure of exposure, sensitivity, and adaptive capacity and presented in Table 6 below. The LVI-IPCC is on a scale from -1 (least vulnerable) to +1 (most vulnerable) and based on the result of the calculation of LVI-IPCC (Eq. 5), high values of exposure relative to adaptive capacity yield positive vulnerability scores while low values of exposure relative to adaptive capacity yield negative vulnerability scores. The sensitivity factor acts as a multiplier, such 
Table 6 Calculated indices for contributing factors and the Livelihood Vulnerability Index under the LVI-IPCC framework

\begin{tabular}{lllll}
\hline AES & Exposure & Sensitivity & Adaptive capacity & LVI-IPCC \\
\hline Highland & 0.324 & 0.626 & 0.623 & -0.187 \\
Midland & 0.142 & 0.429 & 0.679 & -0.231 \\
Wetland & 0.348 & 0.578 & 0.601 & -0.146 \\
Lowland & 0.607 & 0.685 & 0.426 & 0.124 \\
\hline
\end{tabular}

that high sensitivity in an AES for which exposure exceeds adaptive capacity will result in a large positive (i.e., high vulnerability) LVI-IPCC score.

The LVI-IPCC analysis yielded - 0.231, - 0.187, - 0.146, and 0.124 for midland, highland, wetland, and lowland AESs respectively (Table 6). According to this result, the relative exposure is high $(0.607)$ and adaptive capacity is low (0.426) for lowland AES. This result in positive LVI-IPCC scores was classified here as "highly vulnerable" since it indicates an adaptation capacity deficit and high exposure relative to other AESs. On the contrary, exposure is low (0.142) and adaptive capacity is high (0.679) for midland AES that shows the overall vulnerability is estimated to be low. The wetland and highland AESs exhibit intermediate vulnerability value. The result reveals the variation in the level of exposure, sensitivity, and adaptive capacity of smallholders mixed crop and livestock farmers across agro-ecological systems in the Fincha'a sub-basin.

The livelihood vulnerability indices of the eight major profiles are also summarized in spider diagram (Fig. 2). The spider diagram yielded similar results. In the diagram, the lowland AES scored higher value in almost all exposure and sensitivity components profiles and lower values in adaptive capacity component profiles. Similarly, vulnerability triangle (Fig. 3) depicted the contributing factor scores for exposure, adaptive capacity, and sensitivity. The triangle illustrates that the lowland AES scored higher value in exposure and sensitivity components and lower value in the adaptive capacity component. The higher exposure and sensitivity value as compared to adaptive capacity is an indication of higher level of relative vulnerability. In contrast, the midland AES scored the least exposure and sensitivity value and the highest adaptive capacity value as compared to other AESs, which is an indication of the relative low vulnerability of the midland AES to climate variability and change impacts.

In general, the climate, ecosystem, wealth, and infrastructure profiles are strong determinants of vulnerability. The social and community profiles were other determinants that played an intermediate role with fewer differences among the different agro-ecological systems. The agriculture and technology usage profiles were not major factors as there were few significant differences among the AESs.
In terms of geographic area of the sub-basin, the midland AES accounts the largest (44.7\%), whereas the highland, lowland, and wetland AESs accounts 21.9\%, 18.4\%, and $15 \%$ of the total land area respectively. These further explained that $44.7 \%$ of the sub-basin with rolling plateau and brown to red soils has a relatively low vulnerability to climate variability and change. The estimated LVI-IPCC index further suggests that $18.4 \%$ land area of the lowland with warm semiarid AES of the sub-basin categorized as having the highest relative vulnerability.

The mountainous highland with sloping terrain AES and the wetland with artificial lakes AES (covering a land area of $36.9 \%$ ) have a moderate vulnerability value. If not properly managed with the proper adaptation strategies, the mountainous highland AES can be easily vulnerable due to high risk of land degradation problem verified during focus group discussion and sources from zonal and district agriculture and natural resource offices. Land degradation problems are expected to increase with changing climate and associated extreme weather events coupled with change in land use system. In the highland AES, land degradation in general and soil erosion specifically is a phenomenon that endangers the livelihoods of rural farmers' ability to produce crops and livestock. The wetland AES and the artificial lakes constructed for the generation of hydroelectric power also suffering a lot from the problem of siltation that arises from the highland AES and associated midland AES.

\section{Conclusion and policy implications}

The findings of this study disclose the general as well as agro-ecological system (AES)-specific factors contributing to different components of the vulnerability of the IPCC that include exposure, sensitivity, and adaptive capacity for mixed crop-livestock smallholders' households. The comparison across AESs helps to identify agro-ecological system-specific adaptation strategies.

The result revealed that in Fincha'a sub-basin, exposure is high and adaptive capacity is low for lowland AES. This result in minimum LVI-IPCC scores was classified here as "highly vulnerable" since it indicates an adaptation capacity deficit and high exposure relative to other AESs. The opposite is true for midland AES, in which adaptive capacity exceeds exposure and overall vulnerability estimated to be low. The low vulnerability of midland AES could be attributable to lower exposure and sensitivity, and higher asset ownership (wealth), more developed infrastructure, more community profiles, and relatively well-developed social networks. Similarly, in terms of livelihood capitals, the midland AES scored lower natural capital vulnerability factor and higher financial, physical, human, and social capitals vulnerability factor. The highland and wetland AESs exhibit intermediate vulnerability scores. Generally, there was a small 
difference in the estimated LVI-IPCC score value for the four agro-ecological systems.

The indexed values for each profile and indicators varied evidently across AESs, which provided insight into the design and implementation of AES-specific adaptation strategies for smallholders farmers of the sub-basin. Among the four agro-ecological systems, the lowland AES requires implementing appropriate adaptation strategies like conservation agriculture that provides a viable means for strengthening resilience in agro-ecological systems and livelihoods that advance adaptation goals (IPCC 2014). Particularly, the highland AES requires massive soil and water conservation intervention to reduce the vulnerability; otherwise, the highland and wetland AESs and the benefit of hydroelectric dams constructed by the government will be jeopardized.

Generally, to ensure sustainable agricultural production and to minimize the livelihood vulnerability of the community to climate variability and change, it is advisable to enhance the supply of agricultural technologies (improved seed varieties, fertilizer supply, and irrigation development) that is a bottleneck in the sub-basin. In addition, enhancing community-based participatory watershed management approach based on local knowledge and practices is other area that requires due consideration.

Finally, this study suggests that agro-ecological systembased vulnerability assessment of a sub-basin or landscape level to climate variability and change, and comparison across agro-ecological systems help to identify AES-specific adaptation strategies. The approach is based on the long-term realization of the community residing in the area. Therefore, any strategy designed based on such assessments is applicable to local condition. Moreover, the assessment relates several features of socioeconomic and biophysical attributes of the communities.

\section{Endnotes}

${ }^{1}$ The lowest tiers in the administrative structure of the country

${ }^{2}$ Tropical livestock unit (TLU) conversion factor: camel $=1$, cattle $=0.7$, horse $=0.8$, mule $=0.7$, donkey $=0.5$, sheep/goat $=0.1$, chicken $=0.01$ (source: ILCA, 1990)

\section{Acknowledgments}

We wish to express our profound gratitude to Addis Ababa University, and Addis Ababa Science and Technology University for their financial support in accomplishing this paper. The authors also wish to thank the Ethiopian Meteorological Agency that provided the meteorological data for this work, and the smallholder farmers in the research communities.

\section{Funding}

The data collection, data analysis, and write-up of the study supported by Addis Ababa University, and Addis Ababa Science and Technology University.

\section{Availability of data and materials}

Data sharing is not applicable to this article as no datasets were generated or analyzed during the current study.

\section{Authors' contributions}

IT and BS generated the idea and designed the study. Israel carried out the data collection, data analysis, and write-up. Belay provided statistical assistance, read, and revised the manuscript. Finally, both authors read and approved the final version of the manuscript.

Ethics approval and consent to participate

Not applicable.

\section{Consent for publication}

Not applicable.

\section{Competing interests}

The authors declare that they have no competing interests.

\section{Publisher's Note}

Springer Nature remains neutral with regard to jurisdictional claims in published maps and institutional affiliations.

Received: 17 August 2018 Accepted: 28 November 2018

Published online: 19 February 2019

\section{References}

Adger WN (2006) Vulnerability. Glob Environ Change 16:268-281. https://doi.org/ 10.1016/.gloenvcha.2006.02.006

Amare A, Simane B (2017) Climate change induced vulnerability of smallholder farmers: agroecology-based analysis in the Muger sub-basin of the upper Blue-Nile basin of Ethiopia. Am J Clim Chang 6:668-693. https://doi.org/10. 4236/ajcc.2017.64034

Aryal S, Cockfield G, Maraseni TN (2014) Vulnerability of Himalayan transhumant communities to climate change. Clim Chang 125:193-208. https://doi.org/10 1007/s10584-014-1157-5

Asrat P, Simane B (2017) Characterizing vulnerability of crop-based rural systems to climate change and variability: agro-ecology specific empirical evidence from the Dabus watershed, north-West Ethiopia. Am I Clim Chang 6:643-667. https://doi.org/10.4236/ajcc.e2017.64033

Bezuayehu T (2006) People and Dams: environmental and socio-economic changes induced by a reservoir in Fincha'a watershed, western Ethiopia. Doctoral Thesis Wageningen University. ISBN: 90-8504-449-9

Hydropower-induced land use changes in Fincha'a watershed, western Ethiopia: analysis and impacts. Mountain Research and Development 28(1):72-80. https://doi.org/10.1659/mrd.0811

Byerlee D, Spielman DJ, Alemu D, Gautam M (2007) Policies to promote cereal intensification in Ethiopia: a review of evidence and experience. IFPRI discussion paper no. 707. IFPRI, Washington DC, p 37

Chala D, Belay S, Bamlaku A (2017) Farmers' livelihoods vulnerability to climate variability and change in Didesa Basin southern part of Abay Basin, Ethiopia. In: Filho WL et al (eds) Climate change adaptation in Africa, climate change management. https://doi.org/10.1007/978-3-319-49520-0_17

Chambers R, Conway G (1992) Sustainable rural livelihoods: practical concepts for the 21st century, IDS discussion paper 296. IDS, Brighton, p 33

Conway D (2000) Some aspects of climate variability in the north-east Ethiopian highlands-Wollo and Tigray. Ethiop J Sci 23:139-161

Conway D, Schipper ELF (2011) Adaptation to climate change in Africa: challenges and opportunities identified from Ethiopia. Glob Environ Chang 21:227-237

Cramb RA, Culasero Z (2003) Land care in the Philippines: an evaluation of the land care program in South Cotabato. ACIAR Land care Report No. 3. University of Queensland, Brisbane

CSA/Central Statistical Agency (2012) Agricultural sample survey 2011/2012, volume IV: report on land utilization. Central Statistical Agency, Addis Ababa

CSA/Central Statistical Agency (2013) Population projection of Ethiopia for all regions at district level from 2014-2017. The Federal Democratic Republic of Ethiopia, Addis Ababa

Cutter SL, Mitchell JT, Scott MS (2000) Revealing the vulnerability of people and places: a case study of Georgetown County, South Carolina. Ann Am Assoc Geogr 90:713-737

Dechassa L (2003) Surplus producing eastern highland parts of eastern Wallagga zone badly hit by the current crisis. Assessment report submitted to the Office for the Coordination of Human Affairs, UN, Addis Ababa 
Demeke AB, Keil A, Zeller M (2011) Using panel data to estimate the effect of rainfall shocks on smallholders food security and vulnerability in rural Ethiopia. Clim Chang 108:185-206

Denekew A, Bekele S (2009) Characterization and atlas of the Blue Nile Basin and its sub basins. International Water Management Institute, Addis Ababa

Dercon S, Hoddinott J, Woldehanna T (2005) Vulnerability and shocks in 15 Ethiopian villages, 1999-2004. J Afr Econ 14:559-585

Deressa TT (2006) Measuring the economic impact of climate change on Ethiopian agriculture: Ricardian approach. CEEPA Discussion Paper No. 25. Centre for Environmental Economics and Policy in Africa. University of Pretoria, Ababa

Diao X, Pratt AN (2007) Growth options and poverty reduction in Ethiopia-an economy-wide model analysis. Food Policy 32:205-228

Etwire PM, Al-Hassan RM, Kuwornu JKM, Osei-Owusu Y (2013) Application of livelihood vulnerability index in assessing vulnerability to climate change and variability in northern Ghana. J Environ Earth Sci 3:157-170

Evangelista P, Young N, Burnett J (2013) How will climate change spatially affect agriculture production in Ethiopia? Case studies of important cereal crops. Climatic Change, 119 (2013), pp. 855-873. https://doi.org/10.1007/s10584-013-0776-6.

Füssel H (2007) Vulnerability: a generally applicable conceptual framework for climate change research. Glob Environ Chang 17(2):155-167

Füssel HM, Klein RJT (2006) Climate change vulnerability assessments: an evolution of conceptual thinking. Clim Chang 75:301-329

Gutu T, Bezabih E, Mengistu K (2012) Analysis of vulnerability and resilience to climate change induced shocks in north Shewa. Ethiopia. J Agric Sci 3:871-888

Hahn MB, Riederer AM, Foster SO (2009) The livelihood vulnerability index: a pragmatic approach to assessing risks from climate variability and change-cases study in Mozambique. Glob Environ Chang 19:74-88

Hurni H (1993) Land degradation, famine and land resources: scenarios in Ethiopia. In: Pimental D (ed) Soil Erosion and conservation. Cambridge University Press, Cambridge, pp 27-62

ICRISAT/International Crops Research Institute for the Semi-Arid Tropics (ICRISAT) (2006). Retrieved November 21, 2017, from the ICRISAT website: www.icrisat.org/what-we-do/

ILCA/International Livestock Centre for Africa (1990) Livestock Systems Research Manual. Working Paper 1, Vol. 1. ILCA, Addis Ababa, p 287

IPCC/Intergovernmental Panel on Climate Change (2001) Climate Change 2001: impacts, adaptation, and vulnerability. In: McCarthy JJ et al (eds) The contribution of working group $\|$ to the third assessment report of the intergovernmental panel on climate change. Cambridge University Press, Cambridge

IPCC/Intergovernmental Panel on Climate Change (2007) Summary for policymakers. In: Parry ML, Canziani OF, Palutikof JP, van der Linden PJ, and C.E. Hanson, Eds., Climate change 2007: impacts, adaptation, and vulnerability, contribution of working group II to the fourth assessment report of the intergovernmental panel on climate change, Cambridge University Press, Cambridge, 7-22

IPCC/Intergovernmental Panel on Climate Change (2014) Emergent risks and key vulnerabilities. In: Field CB, Barros VR, Dokken DJ, Mach KJ, Mastrandrea MD, Bilir TE, Chatterjee M, Ebi KL, Estrada YO, Genova RC, Girma B, Kissel ES, Levy AN, MacCracken S, Mastrandrea PR, White LL (eds) Climate change 2014: impacts, adaptation, and vulnerability. Part a: global and sectoral aspects. The contribution of working group II to the fifth assessment report of the intergovernmental panel on climate change

Kassie BT, Rotter RP, Hengsdijk H, Asseng S, Vanittersum MK, Kahiluoto H, Vankeulen H (2014) Climate variability and change in the central Rift Valley of Ethiopia. J Agric Sci 152:58-74

Kelly PM, Adger WN (2000) Theory and practice in assessing vulnerability to climate change and facilitating adaptation. Clim Chang 47:325-352

Kim U, Kaluarachchi JJ (2009) Climate Change Impacts on Water Resources in the Upper Blue Nile River Basin, Ethiopia. Journal of the American Water Resources Association (JAWRA) 45(6):1361-1378. https://doi.org/10.1111/j. 1752-1688.2009.00369.x

Kindie T, Jemal S, Mezegebu G, Girma M (2016) Agriculture under a changing climate in Ethiopia: challenges and opportunities for research. Ethiopia Institute of Agricultural Research (EIAR) 50th Year Jubilee Anniversary Special Issue, pp 67-86

Mohan D, Sinha S (2010) Vulnerability assessment of people, livelihoods and ecosystems. WWF-India Retrieved from CAKE http://www.cakex.org/virtuallibrary/3458. Accessed 05 July 2018
MoWIE/Ministry of Water, Irrigation, and Electricity (2014) Preparation of watershed projects, Fincha'a'a catchment, Nile cooperation for results project. The Federal Democratic Republic of Ethiopia, Addis Ababa

Nelson GC, Rosegrant MW, Palazzo A, Gray I, Ingersoll C, Robertson R, Tokgoz S, Zhu T, Sulser TB, Ringler C, Msangi S, You L (2010) Food security, farming, and climate change to 2050: scenarios, results, policy options. IFPRI Research Monograph, Washington, DC, p 130

O'Brien K, Eriksen S, Nygaard LP, Schjolden A (2007) Why different interpretations of vulnerability matter in climate change discourses. Clim Pol 7(1):73-88

O'Brien K, Leichenko R, Kelkar U, Venema H, Aandahl G, Tompkins H (2004) Mapping vulnerability to multiple stressors: climate change and globalisation in India. Glob Environ Chang 14:303-313. https://doi.org/10.1016/j.gloenvcha. 2004.01.001

Pandey R, Jha S (2012) Climate vulnerability index-measure of climate change vulnerability to communities: a case of rural lower Himalaya, India. Mitig Adapt Strategy Glob Chang 17:487-506. https://doi.org/10.1007/s11027-011-9338-2

Panthi J, Dahal P, Shrestha ML, Aryal S, Krakauer NY, Pradhanang SM, Lakhankar T, Jha AK, Sharma M, Karki R (2015) Spatial and temporal variability of rainfall in the Gandaki River basin of Nepal Himalaya. Climate 3:210-226

Pretty J (2003) Social capital and the collective management of resources. Science 302:1912-1914

Seleshi Y, Zanke U (2004) Recent changes in rainfall and rainy days in Ethiopia. Int J Climatol 24:973-983

Shah KU, Dulal HB, Johnson C, Baptiste A (2013) Understanding livelihood vulnerability to climate change: applying the livelihood vulnerability approach to assessing climate change impacts on mixed agro-livestock. . livelihood vulnerability index in Trinidad and Tobago. Geoforum 47:125-137. https://doi.org/10.1016/j.geoforum.2013.04.004

Simane B, Zaitchik BF, Foltz JD (2014) Agro-ecosystem specific climate vulnerability analysis: application of the livelihood vulnerability index to a tropical highland region. Mitig Adapt Strateg Glob Chang 21:39-65. https://doi.org/10.1007/s11027-014-9568-1

Sullivan C, Meigh JR, Fediw TS (2002) Derivation and testing of the water poverty index phase 1, Final Report. Department for International Development, UK

Temesgen D, Hassan RM, Alemu T, Yesuf M, Ringler C (2008) Analyzing the determinants of farmers' choice of adaptation methods and perceptions of climate change in the Nile basin of Ethiopia. IFPRI Discussion Paper 00798. Environment and Production Technology Division, Washington, DC

Tesfaye K, Mamo G, Debela S, Tadesse M, Mekuriaw A, Debele B, Semane B, Gebrekidan B, Lemenih M, Zenebe M, Gebru G, Alemaw G, Assefa G, Georgis K, Desta S, Mengistu S, Berhanu W, Zenebe M (2015) First assessment report on agriculture and food security. Working group li- climate change impact, vulnerability, adaptation, and mitigation. Ethiopian Panel on Climate Change (EPCC), Ethiopian Academy of Sciences (EAS), Addis Ababa, p 230

Turner BL II, Kasperson RE, Matsone PA, McCarthy JJ, Corellg RW, Lindsey Christensene NE et al (2003) A framework for vulnerability analysis in sustainability science. PNAS 100:8074-8079

UNDP/ United Nation Development Program (2007) Human development reports. Retrieved from: http://hdr.undp.org/sites/default/files/reports/268/ hdr_20072008_en_complete.pdf

Woldeamlak B (2009) Rainfall variability and crop production in Ethiopia: a case study in Amhara region. In: Ege S, Aspen H, Teferra B, Bekele S (eds) Proceedings of the 16th international conference of Ethiopian studies, Trondheim, pp 823-836

World Bank (2006) Sustainable Land Management: Challenges, Opportunities, and Trade-offs. World Bank Publications: Washington, DC. https://elibrary. worldbank.org/doi/abs/10.1596/978-0-8213-6597-7

World Bank (2010) Economics of adaptation to climate change, Ethiopia. Washington DC https://openknowledge.worldbank.org/handle/10986/12504 